\section{Manobra de Recrutamento Alveolar em Anestesia: Como, Quando e Por Que Utilizá-la.}

(Rev Bras Anestesiol, 2005;55:631-638)

Sra. Editora,

Foi com grande interesse que li o artigo referenciado. Gostaria de parabenizar os autores pela invejável iniciativa. Preocupado em esclarecer alguns aspectos, me ocorreu fazer algumas observações:

1) Os autores atribuíram o colapso alveolar à anestesia geral com ventilação mecânica associada à volumes correntes entre 12 e $15 \mathrm{~mL} . \mathrm{kg}^{-1}$. É verdade que altos volumes correntes podem causar hiperinsuflação alveolar, compressão de capilar pulmonar adjacente e inadequada troca gasosa, porém esse tipo de ventilação vem sendo utilizado há vários anos sem, no entanto, existirem evidências de prejuízo ao paciente durante a cirurgia. Hedenstierna ${ }^{1}$ chama a atenção como principais causas de colapso alveolar a perda do tônus muscular e o uso de altas frações inspiradas de oxigênio $\left(\mathrm{FiO}_{2}\right)$. Áreas de atelectasia ocorrem em quase $90 \%$ de todos os pacientes anestesiados, seja sob ventilação espontânea, seja após paralisia muscular, com e sem óxido nitroso e ainda sob anestesia geral venosa ou inalatória ${ }^{1}$.

2) O método CPAP (pressão positiva contínua nas vias aéreas), referido pelos autores como o mais utilizado na literatura, é factível apenas em pacientes sob ventilação espontânea. Smith e col. ${ }^{2}$ utilizaram níveis de $12 \pm 2$ $\mathrm{cmH}_{2} \mathrm{O}$ em anestesia geral sob ventilação espontânea para cirurgia oncológica de mama com aumento dos níveis de $\mathrm{PaO}_{2}$ e diminuição da $\mathrm{PaCO}_{2}$, contrastando com os níveis de 30 a $40 \mathrm{cmH}_{2} \mathrm{O}$ referidos no trabalho supracitado. Uma opção aos pacientes que tenham planejamento para relaxamento muscular durante a cirurgia seria a realização da indução anestésica com CPAP e a sua manutenção com baixos níveis de PEEP (pressão expiratória final positiva) ${ }^{3}$.

3) Os autores defenderam a pesquisa da $\mathrm{PaO}_{2}$ e da relação $\mathrm{PaO}_{2} / \mathrm{FiO}_{2}$ como monitores da eficácia das trocas gasosas pulmonares e ainda referiram como ventilação inadequada a ausência da PEEP. Em um estudo utilizando pacientes obesos e não-obesos, Yoshino e col. ${ }^{4}$ demonstraram que a diminuição da relação $\mathrm{PaO}_{2} / \mathrm{FiO}_{2}$ foi observada apenas em pacientes obesos e com sobrepeso, ventilados sem a realização da manobra de recrutamento alveolar (MRA) e sem o uso da PEEP.

4) O uso da PEEP parece realmente complementar a ação da MRA, porém é importante lembrar que após a descontinuação da PEEP pode ocorrer recolapso alveolar e esse efeito já pode ser observado dentro de um minuto após cessar a PEEP ${ }^{1}$. Ao se utilizar $\mathrm{FiO}_{2}$ de $40 \%$ em ni- trogênio após MRA as áreas de atelectasia reaparecem lentamente ${ }^{1}$. Wetterslev e col. ${ }^{5}$ afirmaram que é incerto se a MRA pode diminuir a incidência de hipoxemia tardia, pneumonia e outras complicações. Mais estudos são necessários para definir o momento ideal para aplicação da MRA e seu real papel na evolução mais favorável dos pacientes no pós-operatório.

5) Existem outros métodos que também servem para profilaxia do colapso alveolar ${ }^{1}$ : o uso da PEEP isoladamente, a manutenção do tônus muscular e o uso de níveis mais baixos $\mathrm{FiO}_{2}$. Níveis de PEEP entre 5 e $10 \mathrm{cmH}_{2} \mathrm{O}$ têm sido advogados por alguns autores como efetivos em recrutar áreas já colapsadas ${ }^{3,6}$. A redistribuição do fluxo sangüíneo pulmonar causado pela PEEP pode limitar a sua eficácia ${ }^{1}$. O tônus muscular pode ser mantido com o uso da cetamina e com aplicação de estimulação elétrica em nervo frênico ${ }^{1}$. $\mathrm{O}$ efeito protetor da cetamina é prejudicado quando ocorre associação desta com os bloqueadores neuromusculares ${ }^{1}$. Evitando-se a realização da indução anestésica sob máscara com oxigênio a 100\% não ocorre colapso alveolar durante a anestesia ${ }^{1}$. O uso de óxido nitroso com a finalidade de diminuir a $\mathrm{FiO}_{2}$ não impede a formação de atelectasia por absorção ${ }^{1}$ e estudos em animais já mostraram que sua absorção na mistura com oxigênio é quase tão rápida quanto o oxigênio a $100 \%{ }^{4}$.

Gostaria de cumprimentar os autores pelo belíssimo estudo que nos alertou para a possibilidade de otimização de nossa técnica anestésica com a finalidade de beneficiar o paciente.

Atenciosamente,

Fabiano Timbó Barbosa, TSA

\section{Aveolar Recruitment Maneuver in Anesthetic Practice: How, When and Why it May be Useful}

(Rev Bras Anestesiol, 2005;55:631-638)

Mrs. Editor,

It was with great interest that I read the above-mentioned article published by our respectful journal. I would like to congratulate the authors for the appreciable initiative. Concerned with explaining some aspects, I thought about making some observations:

1) Authors have attributed alveolar collapse to general anesthesia under mechanical ventilation associated to tidal volumes between 12 and $15 \mathrm{~mL} \cdot \mathrm{kg}^{-1}$. It is true that high tidal volumes may promote alveolar hyperinflation, adjacent pulmonary capillary compression and inadequate gas 
exchange, however this type of ventilation has been used for several years without evidences of problems to patient during surgery. Hedenstierna ${ }^{1}$ calls the attention for the loss of muscle tone and the use of high oxygen inspired fractions $\left(\mathrm{FiO}_{2}\right)$ as the major causes of alveolar collapse. Atelectasis is seen in $90 \%$ of all anesthetized patients, be it under spontaneous ventilation or after muscle paralysis, with and without nitrous oxide, and also under intravenous or inhalational general anesthesia ${ }^{1}$.

2) CPAP (continuous positive airway pressure), referred by the authors as the most popular method in the literature, is only feasible for patients under spontaneous ventilation. Smith et al. ${ }^{2}$ have used $12 \pm 2 \mathrm{cmH}_{2} \mathrm{O}$ in general anesthesia under spontaneous ventilation for breast oncologic surgery with increased $\mathrm{PaO}_{2}$ and decreased $\mathrm{PaCO}_{2}$ levels, contrasting with 30 to $40 \mathrm{cmH}_{2} \mathrm{O}$ referred on the above-mentioned study. An option to patients to be submitted to muscle relaxation during surgery would be anesthetic induction with CPAP and anesthetic maintenance with low PEEP levels (positive end expiratory pressure) ${ }^{3}$.

3) Authors advocated $\mathrm{PaO}_{2}$ and $\mathrm{PaO}_{2} / \mathrm{FiO}_{2}$ ratio to monitor pulmonary gas exchange and have also related inadequate ventilation to lack of PEEP. In a study with obese and non obese patients, Yoshino et al. ${ }^{4}$ have shown that decreased $\mathrm{PaO}_{2} / \mathrm{FiO}_{2}$ ratio was only observed in obese and overweighed patients ventilated without alveolar recruitment maneuver (ARM) and without PEEP.

4) PEEP seems really to complement ARM action, however it is important to remember that after PEEP withdrawal there may be alveolar re-collapse and that this effect may already be observed one minute after PEEP discontinuation ${ }^{1}$. With $40 \% \mathrm{FiO}_{2}$ in nitrogen after ARM, atelectasis areas slowly reappear ${ }^{1}$. Wetterslev et al. ${ }^{5}$ state that it is not certain that ARM may decrease the incidence of late hypoxemia, pneumonia and other complications. Further studies are needed to define the optimal ARM time and its real role in the more favorable postoperative evolution of patients.

5) There are other methods to prevent alveolar collapse 1: PEEP alone, muscle tone maintenance and lower $\mathrm{FiO}_{2}$. PEEP levels between 5 and $10 \mathrm{cmH}_{2} \mathrm{O}$ have been advocated by some authors as effective to recruit already collapsed areas ${ }^{3,6}$. PEEP-induced pulmonary flow redistribution may limit its efficacy ${ }^{1}$. Muscle tone should be maintained with ketamine and phrenic nerve electric stimulation ${ }^{1}$. Ketamine protective effect is impaired with its association with muscle relaxants ${ }^{1}$. There will be no alveolar collapse during anesthesia if anesthetic induction under mask with $100 \%$ oxygen is avoided ${ }^{1}$. Nitrous oxide to decrease $\mathrm{FiO}_{2}$ does not prevent atelectasis by absorption ${ }^{1}$ and animal studies have shown that its absorption in the mixture with oxygen is almost as fast as with $100 \%$ oxygen ${ }^{4}$.
I wish to congratulate the authors for their elegant study which has called our attention for the possibility of optimizing our anesthetic technique to benefit patients.

Yours truly

Fabiano Timbó Barbosa, TSA, M.D.

\section{REFERÊNCIAS - REFERENCES}

01. Hedenstierna $G$ - Atelectasis and gas exchange during anaesthesia. Electromedica, 2003;71:70-73.

02. Smith RA, Bratzke EC, Miguel RV - Constant positive airway pressure reduces hypoventilation induced by inhalation anesthesia. J Clin Anesth, 2005;17:44-50.

03. Rusca M, Proietti S, Schnyder P et al - Prevention of atelectasis formation during induction of general anesthesia. Anesth Analg, 2003;97:1835-1839.

04. Yoshino J, Akata T, Takahashi S - Intraoperative changes in arterial oxygenation during volume-controlled mechanical ventilation in modestly obese patients undergoing laparotomies with general anesthesia. Acta Anaesthesiol Scand, 2003;47: 742-750.

05. Wetterslev J, Hansen EG, Roikjaer O et al - Optimizing preoperative compliance with PEEP during upper abdominal surgery: effects on perioperative oxygenation and complications in patients without preoperative cardiopulmonary dysfunction. Eur J Anaesth, 2001;18:358-365.

06. Coussa M, Proietti S, Schnyder P et al - Prevention of atelectasis formation during the induction of general anesthesia in morbidly obese patients. Anesth Analg, 2004;98:1491-1495.

\section{Réplica}

\section{Sra. Editora,}

É com satisfação que recebi a carta do Dr. Fabiano. Agradeço os elogios feitos e gostaria de acrescentar alguns comentários:

1. Realmente os altos volumes correntes são causadores de hiperdistensão e colapso alveolares de forma cíclica como foi citado no nosso artigo. Ele tem razão ao afirmar que em pacientes anestesiados não existem evidências de prejuízo com a utilização de altos volumes, caso esses pacientes não tenham nenhuma doença pulmonar, porém é sabido que esses altos volumes quando utilizados por tempo prolongado são causadores de volutrauma, devendo assim ser evitados em qualquer situação.

2. O CPAP realmente só é possível se utilizar em pacientes com ventilação espontânea, logo só poderia ser utilizado nos pacientes anestesiados quando estes já tivessem em processo de desmame da prótese ventilatória, próximos da extubação. É provável que em pacientes sem doença pulmonar, os níveis de pressão para obter recrutamento sejam menores que 30 a $40 \mathrm{cmH}_{2} \mathrm{O}$, 
como citado pelo Dr. Fabiano no trabalho de Smith e col. Esses níveis de pressão de 30 a $40 \mathrm{cmH}_{2} \mathrm{O}$ citados por nós foram utilizados em pacientes com SDRA, ou seja, pacientes com complacência pulmonar reduzida ${ }^{1,2}$.

3. Defendemos a avaliação da $\mathrm{PaO}_{2}$ ou da relação $\mathrm{PaO}_{2} /$ $\mathrm{FiO}_{2}$ como modo de verificar a eficácia do recrutamento alveolar por ser o método mais simples e de baixo custo comparativamente com o outro método descrito na literatura, que é a tomografia de tórax. A conclusão feita por Yoshino e col. observando que pacientes obesos e com sobrepeso, ventilados sem realização de manobra de recrutamento ou uso de PEEP, evoluíram com diminuição da relação $\mathrm{PaO}_{2} / \mathrm{FiO}_{2}$ vai de encontro aos resultados da literatura. Quando existem fatores que alteram a mecânica ventilatória ou doenças pulmonares, maior é a probabilidade de formação de atelectasias e maior a importância da ventilação adequada.

4. O Dr. Fabiano está correto com relação ao fato de que "mais estudos são necessários para definir o momento ideal para a aplicação da manobra de recrutamento alveolar e seu real papel na evolução dos pacientes", indo de encontro às nossas conclusões de que o uso rotineiro da manobra de recrutamento em anestesia não pode ser recomendado por não ter embasamento em estudos com alto nível de evidência.

5. O uso da PEEP e baixa $\mathrm{FiO}_{2}$ são, sem dúvida, métodos eficazes na profilaxia do colapso alveolar.

Tentamos com essa revisão da literatura trazer para o conhecimento do anestesiologista práticas de terapia intensiva que podem ajudar a solucionar algumas complicações anestésicas. Agradecemos muito ao Dr. Fabiano pela oportunidade de discutirmos novamente este tema.

\section{Domingos Dias Cicarelli, TSA}

\section{Reply}

Mrs. Editor,

I was happy to receive Dr. Fabiano's flattering letter. I thank for the praises and would like to add some comments:

1. In fact, high tidal volumes promote cyclic alveolar hyperdistension and collapse as mentioned in our study. $\mathrm{He}$ is right when stating that there are no evidences of problems in anesthetized patients with high volumes, provi- ded patients have no pulmonary disease; however it is known that such high volumes when used for a long time may promote volutrauma and should be avoided in any situation.

2. In fact, CPAP can only be used in patients under spontaneous ventilation, so it could only be used in anesthetized patients being weaned from ventilatory prosthesis and close to extubation. It is possible that, in patients free from pulmonary disease, pressure levels for recruitment are lower than 30 to $40 \mathrm{cmH}_{2} \mathrm{O}$, as mentioned by Dr. Fabiano in the study by Smith et al. These pressure levels of 30 to $40 \mathrm{cmH}_{2} \mathrm{O}$ mentioned by us were used in patients with ARDS, that is, patients with decreased pulmonary compliance ${ }^{1,2}$.

3. We advocate $\mathrm{PaO}_{2}$ or $\mathrm{PaO}_{2} / \mathrm{FiO}_{2}$ ratio evaluation to check alveolar recruitment efficacy because it is simpler and of lower cost as compared to the other method described in the literature, which is chest tomography. Yoshino et al.'s conclusion, after observing that obese and overweighed patients ventilated without recruitment maneuver or PEEP evolved with decreased $\mathrm{PaO}_{2} / \mathrm{FiO}_{2}$ ratio, is in line with the literature. When there are facts changing ventilatory mechanics or in the presence of pulmonary diseases, there is higher possibility of atelectasis and higher is the importance of adequate ventilation.

4. Dr. Fabiano is right with regard to the fact that "further studies are needed to define the optimal ARM time and its real role in the more favorable evolution of patients" and is in line with our conclusions that routine recruitment maneuver in anesthesia cannot be recommended because it is not based on studies with high levels of evidence.

5. PEEP and low $\mathrm{FiO}_{2}$ are undoubtedly effective methods to prevent alveolar collapse.

With this literature review we tried to bring to anesthesiologists intensive care practices which may help solving some anesthetic complications.

We greatly thank Dr. Fabiano for the opportunity to further discuss this subject.

Domingos Dias Cicarelli, TSA, M.D.

\section{REFERÊNCIAS - REFERENCES}

01. Carvalho CRR - Ventilação Mecânica I. Clínicas Brasileiras de Medicina Intensiva, 1를 Ed, São Paulo, Atheneu, 2000.

02. Carvalho CRR - Ventilação Mecânica II. Clínicas Brasileiras de Medicina Intensiva, 1 ${ }^{\text {a }}$ Ed, São Paulo, Atheneu, 2000. 